\title{
Claims to Information Qua Information and a Structural Theory of Section 101
}

\section{KEVIN EMERSON COLLINS*}

Abstract: In this article, I start from the premises that claims to inventive information qua information are not and should not be patentable, and I pursue two lines of inquiry.

First, I argue that a structural theory of Section 101 of the Patent Act provides a policy-driven, conceptually coherent and statutorily justified interpretation that explains why claims to inventive information qua information should be excluded from the realm of patentable subject matter. In brief, patentable subject matter must be restricted in this manner to preserve the duality of claiming and disclosing upon which the entire patent regime is constructed.

Second, I raise the line-drawing problem that I believe to be the most significant obstacle to an administrable implementation of a structural theory of Section 101. The breadth or polyvalency of the concept of information suggests that many things that we currently treat as patentable, if not all of them, are also information. We must develop a more refined taxonomy of the different types of informationality that material things possess in order to sort the patentable claims to information from the unpatentable ones. Because the immateriality of the things described by a claim is not an acceptable proxy for their informationality, the Federal Circuit's recent opinion in In re Nuijten that addresses intangibility as a restriction on patentable subject matter is not a useful starting point for this project.

\footnotetext{
- Associate Professor of Law, Indiana University School of Law, Bloomington. This article is a refinement of a presentation that I gave at The Future of Patent Reform conference at The Ohio State University Moritz College of Law. I thank Mark Lemley, Michael Risch and Polk Wagner for their insights.
} 


\section{INTRODUCTION}

Inventive information qua information should not be patentable. Patents should allow inventors to control some "things" that embody inventive information, but not the inventive information itself. ${ }^{1}$ A simple example illustrates that these assertions are uncontroversial, bedrock principles of contemporary patent protection. Assume that an inventor discovers, isolates and purifies Protein X. She may be able to claim "Protein X in its purified and isolated form" as an embodiment of the inventive information, ${ }^{2}$ but she clearly cannot claim "a representation of the structure of Protein X recorded on a tangible medium." The information that demonstrates why a claimed invention is inventive is a public domain resource that is and should be "exacted from" the patentee and given to the public without restriction as a condition of the patentee's right to exclude from the patentable embodiments of an invention. ${ }^{3}$

My goal in this article is not to defend at length the normative assertion that blatant claims to inventive information qua information like the above claim to a tangible representation are not and should not be patentable. 4 As it applies to the most blatant of claims to information qua information, this assertion is uncontroversial, both descriptively and normatively. Even commentators who defend an expansionist view of patent protection assume that inventive information itself escapes the net of property cast by patent law. 5

\footnotetext{
1I use the term "things" (and other related terms such as "inventions") loosely and recursively. It is loose in that both objects and processes are things that can infringe patents. It is recursive in that it refers both to thing-tokens (instances of things in the extensional world that infringe patents) and thing-types (the conceptual categories to which the thing-tokens belong). Cf. Michael J. Madison, Law as Design: Objects, Concepts, and Digital Things, 56 CASE W. RES. L. REV. 381, 382-83 (2005) (exploring the relationship between law and things).
}

${ }^{2}$ But cf. infra note 16 (noting that "products of nature" are not patentable subject matter if they are merely discovered by the patent applicant).

3 Eldred v. Ashcroft, 537 U.S. 186, 216 (2003) ("[I]mmediate disclosure is not the objective of, but is exacted from, the patentee. It is the price paid for the exclusivity secured.")

(citing J.E.M. Ag Supply Inc. v. Pioneer Hi-Bred Int'l, Inc., 534 U.S. 124, 142 (2001)).

4 But see infra notes $54-56$ and accompanying text (offering a summary justification for such a rule).

5 See, e.g., R. Polk Wagner, Information Wants to Be Free: Intellectual Property and the Mythologies of Control, 103 COLUM. L. REV. 995, 1010 (2003) (suggesting "that even fully 'propertized' intellectual goods will nonetheless contribute, perhaps significantly, to the 
Furthermore, the Patent and Trademark Office ("PTO") and the United States Court of Appeals for the Federal Circuit ("Federal Circuit") would find a reason to deny or invalidate respectively blatant claims to information qua information, although the exact reasoning that they would employ is unclear. Rather, starting from the premises that blatant claims to information qua information are not and should not be patentable, I pursue two subsidiary goals.

First, I articulate the bare bones of a structural theory of Section 101 of the Patent Act to explain why the logic and statutory text of the patent laws dictate that inventive information qua information should be unpatentable subject matter. ${ }^{6}$ To invalidate claims to information qua information under Section 101, courts must go beyond the plain meaning of the section's literal text viewed in isolation to understand the meaning of the statute. Section 101 must be interpreted in light of the structure of the Patent Act as a whole and, more specifically, in light of the "duality of claiming and disclosing" on which the entire patent regime is premised.7 Courts should use Section 101 to enforce the disclosure obligation of the inventor and patentee-the obligation to place inventive information qua information in the public domain without any strings attached-and thus to protect the disclosure side of the duality from inefficient encroachment by the claiming side.

Second, I raise (but do not resolve) a line-drawing problem for a structural theory that follows from the breadth of the contemporary notion of information. The problem is not whether there is such a thing as inventive information qua information that is and should remain unpatentable subject matter under Section 101. Clearly, there is. Rather, the problem is whether a policy-driven and administrable limiting principle can be found to make the process of identifying claims to information qua information anything other than the uncertain and evolving "I know it when I see it" test that it has been up to this point. ${ }^{8}$ The distinction between a claim to a patentable embodiment and a claim to unpatentable information qua

growth of open information" because intellectual property just does not propertize information itself).

${ }^{6} 35$ U.S.C. $§ 101$ (2007).

7 Graeme B. Dinwoodie \& Rochelle Cooper Dreyfuss, Patenting Science: Protecting the Domain of Accessible Knowledge, in THE FUTURE OF THE PUBLIC DOMAIN: IDENTIFYING THE COMMONS IN INFORMATION LAW 192, 193 n.4 (Lucie Guibault \& P. Bernt Hugenholtz eds., 2006).

8 Jacobellis v. Ohio, 378 U.S. 184, 197 (1964) (Stewart, J., concurring) (discussing the identification of pornography that is unprotected by the First Amendment). 
information is an intuitive one in many easy cases. At first glance, we do know the difference between a claim to "isolated and purified Protein X" and "a tangible representation of the structure of Protein X" when we see it. However, there will also be many difficult cases that lie in a gray, murky area where different intuitions lead in different directions. Upon closer examination, many routinely patentable embodiments of inventions such as computer software and DNA are reasonably described as nothing more than information recorded on a tangible medium.

The murkiness is attributable in part to the fact that the immateriality of a claimed invention is not an effective proxy for its informationality. (Thus, the Federal Circuit's recent opinion in In re Nuijten 9 holding that claims to relatively immaterial, informationbearing signals do not recite patentable subject matter should not distract us from the goal of shielding information qua information from patentability.) To identify unpatentable claims to inventive information qua information and to distinguish them from information-intensive claims that do recite patentable subject matter, a structural theory of Section 101 requires a yet-to-be-developed taxonomy of the different kinds of informationality that tangible resources can possess.

This article proceeds in three steps. Section II offers a status report on the confused state of the contemporary patentable subject matter doctrine. Section III outlines my proposal for a structural theory of Section 101 that, if adopted, would provide a policy-driven, conceptually coherent and statutorily justified basis for invalidating claims to inventive information qua information. Section IV explores the difficulty of distinguishing patentable information from unpatentable information.

\section{A STATUS REPORT ON SECTION 101}

Section 101 of the Patent Act authorizes the courts and the PTO to act as gate-keepers for the realm of patentable things. The basic thrust of this patentable subject matter doctrine is that there are some types of progress that just should not be propertized by patents, regardless of how inventive, well-described, and useful they are to society.

The practical importance of Section 101 diminished during the 1980 s and 1990s. It is a familiar story that during this time period the

9 In re Nuijten, 500 F.3d 1346 (Fed. Cir. 2007). 
propertizing reach of the patent regime grew as more and more of what was once presumed to be unpatentable (e.g. software and business methods) became de jure patentable and de facto patented. ${ }^{10}$ This erosion can be described with any of three different stories. A doctrinal recounting of the erosion focuses on, first, the establishment of a default in favor of patentability in Diamond $v$. Chakrabarty outside of an enumerated set of classes of discoveries that are excluded from patentability, ${ }^{11}$ and, second, the gradual, postChakrabarty erosion of both the number and scope of those excluded classes. A policy-oriented description of the same events casts Section 101 doctrine as a doctrine that is both economically unjustifiable and costly to administer. ${ }^{12}$ A more nuanced variant casts Section 101 as the vestigial appendix of patent doctrine. Perhaps it served a useful function in the past, but today it is no longer necessary because any claim that is unpatentable under the patentable subject matter doctrine is also invalid under one of the now-refined invalidity doctrines. ${ }^{33}$ Finally, a plain-meaning textualist telling the same story might merely note that there is little to no statutory support for the exclusions as Section 101 merely states that "any new and useful process, machine, manufacture, or composition of matter" is a patentable invention. ${ }^{14}$ Importantly, these three stories are mutually

\footnotetext{
10 Growth in the number of privatizable things is not a phenomenon specific to patents among intellectual property regimes. See James Boyle, The Second Enclosure Movement and the Construction of the Public Domain, 66 LAW \& CONTEMP. PROBS. 33, 37-40 (2003) (arguing that " $[\mathrm{w}] \mathrm{e}$ are in the middle of a second enclosure movement").
}

"Diamond v. Chakrabarty, 447 U.S. 303, 309 (1980) (holding that "anything under the sun that is made by man" can fall within the scope of Section 101 but that "laws of nature, physical phenomena, and abstract ideas" do not).

${ }^{12}$ See F. Scott Kieff, The Case for Registering Patents and the Law and Economics of Present Patent-Obtaining Rules, 45 B.C. L. REv. 55, 108 (2003).

${ }^{13}$ See Michael Risch, Everything is Patentable (on file with author). Cf. Kristen Osenga, Ants, Elephant Guns, and Statutory Subject Matter, 39 ARIZ. ST. L.J. 1087 (arguing that the statutory subject matter requirement has no special role to play in determining the validity of claims to computer software).

${ }^{14} 35$ U.S.C. § 101 (2007). A textual argument supporting limits on statutory subject matter can also be made based on the Constitution, which grants Congress the authority to promote progress in the "useful Arts." U.S. CONST. art. I, \& 8, cl. 8. It is therefore possible to argue that patentable subject matter encompasses something like the "technological arts" but not the "liberal arts." Compare In re Musgrave, 431 F.2d 882, 893 (C.C.P.A. 1970) (creating a soon-to-be-rejected "technological arts" test); with Ex parte Lundgren, No. 2003-2088, 2005 Pat. App. LEXIS 34, at *5-12 (B.P.A.I. Sept. 28, 2005) (rejecting a "technological arts" test). See also John R. Thomas, The Patenting of the Liberal 
reinforcing, not conflicting. The set of expressly excluded classes has proven difficult to maintain as a bulwark against the default of patentability precisely because there is no textual justification for the exceptions within the four corners of the text of Section 101, and the list of the set's members reads like an ad hoc collection of ill-defined "no-no's" that lack convincing, policy-driven narratives of justification.

The classes of inventions that are now understood to be excluded from patentable subject matter are most easily described in two groups: those that have been identified and sanctioned by the United States Supreme Court and those that have only been addressed by the lower courts or the PTO.

The Supreme Court has identified a trio of excluded classes: "laws of nature, natural phenomena, and abstract ideas." 15 However, the nature of the inventions that fall within these three excluded classesand whether they are even three separate classes-is difficult to grasp. Most importantly for the discussion here, ${ }^{16}$ the Court has clearly stated that mathematical algorithms are "laws of nature" that cannot be patented in the abstract but that can be patented when applied in methods that are, when "considered as a whole," performing "a function that the patent laws were designed to protect." 17 Precisely why mathematical algorithms are unpatentable when described in the abstract, however, is not clear. One justification is that mathematical algorithms, along with other "laws of nature," are "the basic tools of scientific and technological work." 18 The standard and reductive

Professions, 40 B.C. L. REv. 1139 (1999) (arguing that patentable subject matter has exceeded the bounds of the technological arts).

15 Chakrabarty, 447 U.S. at 309. Although this list is often taken as definitive, the Supreme Court has recited other excluded categories in other opinions.

${ }_{16}$ Because this article focuses on the status of information under Section 101, there are two significant branches of the Supreme Court's jurisprudence on Section 101 that are not discussed. First, products of nature such as plants or minerals that are pre-existing, natural entities and that are merely discovered and brought to society's attention by a patent applicant are not patentable subject matter. See, e.g., In re Bergy, 563 F.2d 1031, 1036 (C.C.P.A 1977). Second, the 1853 Supreme Court case of O'Reilly v. Morse, 56 U.S. 62 (1853), suggests that the patentable subject matter doctrine is also involved in the policing of claim overbreadth, a task that is more commonly performed today under the auspices of the enablement and written description doctrines.

17 Diamond v. Diehr, 450 U.S. 175, 192 (1981).

18 Gottschalk v. Benson, 409 U.S. 63, 67 (1972). Another justification for this rule suggests that man-made and, therefore, patentable "inventions" must be juxtaposed with unpatentable "discoveries" wherein the human contribution to technological progress is 
utilitarian justification for patents identifies one benefit (the incentive to invent generated by the lure of property) and one cost (the static cost of reduced consumption of the material embodiments of progress due to the higher cost of patented goods). ${ }^{19}$

The "basic tools" argument adds one additional cost into the equation: the property in inventions granted to generation $\mathrm{N}$ inventors can impose dynamic costs by slowing down or hindering the work of the inventors in generation $\mathrm{N}+\mathbf{1}^{20}$ When the dynamic costs of patents are taken into account, the justification for patents on "basic tools"-the things that are most commonly used as inputs into ongoing invention by innovative consumers-is weaker than the justification for patents on the types of things most commonly used by passive consumers. However, neither the Supreme Court nor the Federal Circuit has generalized from this "basic tools" rationale to expand the categories of unpatentable subject matter. They have not identified any other categories of things beyond mathematical algorithms that are "laws of nature" in the abstract. ${ }^{21}$

akin to merely dusting off what already existed in nature. See Parker v. Flook, 437 U.S. 584,593 n.15 (1978). Cf. supra note 16 (discussing the invention/discovery distinction in the context of claims to naturally occurring substances). The distinction between inventions and discoveries, however, is in many instances a metaphysical line that is neither easy to draw nor compelling as a proxy for utilitarian concerns.

${ }^{19}$ See, e.g., Graham v. John Deere Co., 383 U.S. 1, 7-11 (1966) (discussing Thomas Jefferson's view of the patent system).

${ }^{20}$ In theory, there are a variety of distinct types of dynamic costs. See, e.g., Michael A. Heller \& Rebecca S. Eisenberg, Can Patents Deter Innovation? The Anticommons in Biomedical Research, 280 SCIENCE 698 (1998), available at http://www.sciencemag.org/ cgi/reprint/280/5364/698.pdf (discussing several distinct factors that contribute to the transaction cost problem that may arise when an inventor of generation $\mathrm{N}+1$ must bundle the rights of the inventors of generation N); Mark A. Lemley, The Economics of Improvement in Intellectual Property Law, 75 TEX. L. REv. 989, 1048-67 (1996) (detailing the strategic bargaining that may occur between an inventor $\mathrm{N}$ and an inventor $\mathrm{N}+1$ with blocking patents); Robert P. Merges \& Richard R. Nelson, On the Complex Economics of Patent Scope, 90 CoLUM. L. REv. 839, 885-88 (1990) (arguing that broad, early patents stifled technological progress in the electrical lighting industry because of a lack of competition for follow-on inventions).

21 The Section 101 "laws of nature" doctrine requires the identification of additional classes or categories of "basic tools" that can be circumscribed ex ante and that are likely to impose uncommonly high dynamic costs when patented. Because the costs will vary over time, case by case analysis of the dynamic costs imposed on future innovation by a particular claim is, if appropriate at all, more in keeping with the spirit of the experimental use exemption than it is with the subject matter patentability doctrine. 
The lower courts defend additional exclusions, often without offering any policy justification at all. During the 1950s and 1960s, the Court of Customs and Patent Appeals rejected claims under a branch of Section 101 called the "mental steps" doctrine, although the contemporary vitality of this doctrine is questionable. ${ }^{22}$ The Federal Circuit still rejects claims to "printed matter" as unpatentable, ${ }^{23}$ but the scope of this exclusion is uncertain due to its entanglement with the historical business method exception from patentable subject matter which has been expressly rejected by the Federal Circuit.24 Extending the printed matter doctrine into the digital age, the PTO has declared its intention to make a distinction between "functional" and "nonfunctional descriptive material" when patent claims describe data stored in digital, computer-readable form.

The PTO allows "functional" software claims to issue but reasons that "nonfunctional" claims, such as those to musical compositions and raw data, are unpatentable under Section 101.25 Although the exclusion of the informational content of songs, books and databases may intuitively seem to produce the "correct" result, the logical reasoning that the PTO uses to distinguish functional from nonfunctional descriptive material is opaque at best. The distinction between "functional" and "nonfunctional" seems to be an entirely pragmatic response to the goal-driven policy of allowing many claims on software but denying the most blatant of claims to inventive information qua information.

Within the last several years, there has been a resurgence in Section 101 cases. The PTO, the Federal Circuit, and even the Supreme Court have all grappled with arguments suggesting that immateriality is in some way a meaningful limit on patentable subject

\footnotetext{
22 Compare In re Comiskey, 499 F.3d 1365, 1378-79 (Fed. Cir. 2007) (embracing the mental steps doctrine), with In re Musgrave, 431 F.2d at 888-89 (rejecting the mental steps doctrine). See also Kevin Emerson Collins, Propertizing Thought, 60 SMU L. REv. $317,355-57$ (2007) (summarizing the history and current status of the mental steps doctrine).

${ }_{23}$ See In re Ngai, 367 F.3d 1336, 1337-39 (Fed. Cir. 2004) (invalidating a claim as anticipated under Section 102 when the only difference between the claimed invention and the prior art resided in the printed matter).
}

24 See State St. Bank \& Trust Co. v. Signature Fin. Group, Inc., 149 F.3d 1368, 1375-77 (Fed. Cir. 1998) (holding that there is no business method exception to patentable subject matter).

25 See Manual of Patent EXamining PRocedure § 2106.01, at 2100-18 (8th ed. rev. 2006). 
matter. ${ }^{26}$ Even if software is patentable when in a moderately tangible state, such as when it is stored on disks or running on programmed machines, perhaps inventions that are yet less tangible-signals when detached from a storage medium (In re Nuijten), ${ }^{27}$ business methods neither executed through software nor requiring a tangible object to implement (In re Comiskey), ${ }^{28}$ and/or mental rather than computer execution of information-processing tasks (Laboratory Corp. $v$. Metabolite Labs.) ${ }^{29}$-should not be patentable.

\section{A STRUCTURAL THEORY OF SECTION 101}

Blatant claims to information qua information suggest that the subject matter patentability doctrine of Section 101 is not a useless, path-dependent appendix of contemporary patent law. $3^{\circ}$ Placing the doctrine of subject matter patentability aside, a blatant claim to information qua information, such as a claim to "a representation of the structure of Protein X recorded on a tangible medium or carried on a signal," arguably satisfies all of the criteria of patent validity under their current judicial interpretations. ${ }^{31}$

\footnotetext{
${ }^{26} \mathrm{~A}$ focus on immateriality is not new to Section 101 argumentation. Immateriality has long played a prominent yet uncertain role in the subject matter patentability doctrine. See Collins, supra note 22, at 346-47 (briefly reviewing the role that intangibility has played in Section 101 doctrine). The immateriality issues currently before the PTO and the courts merely push an old concern into new arenas and deal with a relative degree of immateriality that has never previously been addressed.
}

${ }_{27}$ In re Nuijten, 500 F.3d at $1353-57$ (holding that a claim to a "signal" is not patentable subject matter but not reviewing the PTO's decision to grant a claim to the same information when recorded on a "storage medium").

${ }^{28}$ In re Comiskey, 449 F.3d 1378 (" $[\mathrm{T}]$ he patent statute does not allow patents on particular systems that depend for their operation on human intelligence alone."). See also Ex parte Lundgren, No. 2003-2088, 2005 Pat. App. LEXIS 34, at *134-43 (B.P.A.I. Sept. 28, 2005) (Barrett, A.P.J., dissenting) (arguing that the mental steps doctrine should play an active role in determining patentability); Ex parte Bilski, Appeal No. 2002-2257, Application 08/933/892, at *11 (B.P.A.I. Sept. 26, 2006) (Informative Opinion) (incorporating the dissent in Ex parte Lundgren into the analysis of the majority opinion).

29 Lab. Corp. of Am. Holdings v. Metabolite Labs., Inc., 548 U.S. 124 (2006) (dismissing certiorari as improvidently granted in a case that turned on the patentability of mental reasoning). See also Collins, supra note 22, at 323-42 (framing Lab. Corp. as a case about the propertization of thought).

${ }^{30} \mathrm{Cf}$. supra note 13 and accompanying text.

${ }^{31}$ The exercise of examining what a court without recourse to the subject matter patentability doctrine would do if faced with a blatant claim to information qua 
Assuming that the structure of Protein $\mathrm{X}$ is unknown before the inventor's work, the representation should logically be novel..$^{32}$ To use a pen-and-ink representation as an example, prior to the inventor's work, no sheet of paper existed with marks on it that conveyed the structure of Protein X. In other words, it is not only the semantic content of the writing or representation (i.e., the signified) that is novel. The physical structure of the signs used to convey that content (i.e., the signifier) is also novel.33

Assuming that the representation operates within a conventional technique or language, nonobviousness presents a more difficult

information may resemble tilting at windmills. Because I believe that courts would view such a claim as something that clearly should not be patented, I also believe they would sculpt an exception from some doctrine-any doctrine available-to deny its patentability. My point in the following paragraphs is only that a blatant claim to information qua information should present an easy case of something that cannot be patented, but why it is an easy case is not self-evident until a structural theory is brought to bear on the issue. Claims to inventive information qua information should clearly be different from routinely patentable subject matter, and patent doctrine has yet to develop a robust explanation for why and how they are different.

It is relatively easy to imagine an implementation of a structural theory (i.e. a theory that looks to the structural duality of claiming and disclosing of the Patent Act as a whole in order to interpret individual statutes) that prevents claims to inventive information qua information from issuing in the novelty, nonobviousness and/or utility doctrines. See infra notes 33, 35 and 37. If exceptions to the rules of novelty, nonobviousness and/or utility are made so as to achieve the goal of a structural theory, I will not quibble at length with the doctrinal silo within which the structural theory is housed. However, there are two reasons why Section 101 may provide the better locus for a structural theory. First, there is a truth-in-advertising value in housing the structural theory in Section 101. The structural theory sounds in the rhetoric of Section 101: one particular type of progress, namely progress in the production of inventive information itself, is simply not the kind of progress that we should propertize. Second, at least with respect to a structural theory of either Section 102 or 103, the theory must extend beyond traditional printed matter. The normative and doctrinal reasoning behind the structural theory applies with equal force to both printed and computer-readable information qua information, and I believe that the structural theory may prove very difficult to apply to computer software through manipulation of the novelty and nonobviousness doctrines. Cf. supra note 25 and accompanying text (discussing the "nonfunctional descriptive material" exception to the patentability of software under Section 101).

${ }^{32}$ See 35 U.S.C. $§ 102(a)$ (2007) (codifying the core of the novelty requirement).

33 In In re Ngai, the Federal Circuit implicitly held that the novelty of the representation's signifiers in their specific arrangement is irrelevant in a Section 102 analysis and expressly held that the representation's semantic content is also irrelevant. 367 F.3d at 1338 . This approach can be described as a structural theory of novelty-an approach that modifies the ordinary rules of the novelty inquiry in order to effectuate the policy goal of invalidating claims to inventive information qua information. 
issue.34 How nonobviousness could be determined without reference to the semantic content of the representation is not easy to formulate. An inquiry into whether a person having ordinary skill in the art is motivated to make a particular set of signifiers is meaningless without reference to what the signified means because we make such signs only to communicate semantic content. Furthermore, the nonobviousness inquiry must consider the mental state of the person having ordinary skill in the art (the "PHOSITA"), even in the most traditional of technologies: a widget is nonobvious if and only if the PHOSITA did not conceive of it or have motivation to produce it. Provided that the semantic content of the representation can be considered in a nonobviousness analysis, the claimed representation should logically be nonobvious whenever the structure of Protein X is unknown before the inventor's work. ${ }^{35}$

The claimed invention is also arguably useful under the contemporary utility doctrine..$^{36}$ The use of the representation as a tool to communicate known, specific, and valuable information differentiates it from the chemical intermediates that the courts have found to lack statutory utility. ${ }^{37}$

Finally, the disclosure doctrines do not, on their face, prevent the patenting of blatant claims to inventive information qua information. If the disclosure teaches the structure of Protein $\mathrm{X}$ and/or how to

\footnotetext{
${ }^{34}$ See 35 U.S.C. $\S 103$ (2007) (codifying the nonobviousness requirement).

35 The Federal Circuit has held that the meanings of representations on conventional printed matter cannot in and of themselves demonstrate the statutory nonobviousness of a claim to a representation. In re Gulak, 703 F.2d 1381, 1385 (Fed. Cir. 1983) ("Where the printed matter is not functionally related to the substrate, the printed matter will not distinguish the invention from the prior art in terms of patentability."). This interpretation of the nonobviousness requirements produces a structural theory of Section 103 for conventional printed matter.
}

${ }^{36}$ See 35 U.S.C. $\S 101$ (2007) (codifying the utility requirement); Brenner v. Manson, 383 U.S. 519 (1966) (holding that chemicals lack statutory utility if their only known use is as an input into further experiments); In re Fisher, 421 F.3d 1365, 1371 (Fed. Cir. 2005) (extending Brenner $v$. Manson to ESTs).

37 It is, of course, possible that the courts may incorporate the concerns that underlie the structural theory into the utility doctrine and conclude that claims to information qua information lack statutory utility simply because they represent inventive information. $C f$. In re Nuijten, 500 F.3d at 1365-67 (Linn, J., concurring in part and dissenting in part) (interpreting the utility doctrine so as to encompass concerns about the patentability of information that previously had been considered under the patentable subject matter doctrine). 
assay for it, the claim is enabled and sufficiently described. ${ }^{38}$ The claim is also definite: it describes a bounded and identifiable group of representations so long as one of ordinary skill in the art can distinguish writings that represent Protein X from writings that do not.39

Thus, if the patent regime is to be kept clear of the most selfevident of claims to information qua information, it would seem that the brunt of the work falls most logically to Section 101 and the doctrine of subject matter patentability. This outcome is not jarring to anyone who believes that subject matter patentability has any legs left at all. The bailiwick of patentable subject matter easily assimilates the job of policing against the privatization of inventive information. Many of its current, independent doctrines are clustered around the goal of ensuring that information about inventions remains in the public domain, even if no single doctrine alone accomplishes or expressly articulates that goal as a policy concern. $4^{\circ}$

A structural theory of Section 101, however, does more than merely add a bar on claims to information qua information to the list of ad hoc prohibitions that currently populate the subject matter patentability doctrine. A structural theory of Section 101 provides what many Section 101 doctrines lack: narrative and policy coherence

${ }^{38} 35$ U.S.C. $\S 112$, para. 1 (2007) (codifying the enablement and written description requirements). The problem with claims to inventive information qua information is not that they are too general, abstract, or broad. Consider, for example, a modified version of the claim to a representation of Protein $\mathrm{X}$ that only described representations made following a specific, highly circumscribed convention for showing molecular structure. Such a claim would be narrow and specific, yet it would still be a claim to inventive information qua information.

${ }^{39}$ See id. para. 2 (codifying the claim definiteness requirement). Again, the claim could be modified to encompass only representations of Protein X using a specific convention for illustrating molecular structure and any definiteness problem would be entirely defused.

$4^{\circ}$ See supra notes 22-25 and accompanying text (presenting the mental steps, printed matter, and nonfunctional descriptive material doctrines). The Supreme Court's repeated pronouncement that "abstract ideas" and the like are unpatentable seems like a good place to look for a prohibition on claims to inventive information qua information. See, e.g., Rubber-Tip Pencil Co. v. Howard, 87 U.S. 498, 507 (1874) ("An idea of itself is not patentable."); Le Roy v. Tatham, 55 U.S. 156, 175 (1852) ("A principle, in the abstract, is a fundamental truth; an original cause; a motive; these cannot be patented ...."). However, the Supreme Court's holding often cited for this rule suggests that the prohibition on abstract ideas only serves as a back-up to the disclosure doctrines by imposing a limit on the permissible generality of claim language; see supra note 16 (discussing O'Reilly), and the problem with claims to information qua information is not that their language is too general. See supra note 38 . 
that serves as a breakwater to prevent the further erosion of the doctrine of subject matter patentability.

When patent law is described as being premised on a "duality of claiming and disclosing," 41 what is meant is that patent law generates two distinct entitlements and vests each one in a different party. Claims create one entitlement: a limited right of exclusion that is vested, at least initially, in the inventor. ${ }^{2}$ Disclosures create another: they generate privileges of access and use, 43 and they vest them in the public.44 These qualities alone, however, do not explain the duality of patent law. Many property regimes that are not described as dualistic grant rights to exclude that are limited by public privileges of access. For example, ownership of land confers upon the owner the right to exclude all others except in the instance of necessity, in which the law

\footnotetext{
41 Dinwoodie \& Dreyfuss, supra note 7, at 193 n.4.

${ }^{42}$ See 35 U.S.C. $\$ 154(a)$ (2007) (listing the exclusive rights of a patentee).

${ }_{43}$ The term "privileges" is used here in a Hohfeldian, not a procedural, sense. See Wesley Newcomb Hohfeld, Some Fundamental Legal Conceptions as Applied in Judicial Reasoning, 23 YALE L.J. 16, 30-44 (1913) (classifying "rights" and "privileges" as "jural opposites").
}

44 The Patent Act states that patent applicants must provide "a written description of the invention, and of the manner and process of making and using it, in such full, clear, concise, and exact terms as to enable any person skilled in the art to which it pertains ... to make and use the same ...." 35 U.S.C. § 112 para. 1 (2007). Other statutory provisions require the PTO to publish the patent disclosure and make it available to the public. See id. $\$ 122(b)$ (requiring publication of patent applications eighteen months after their filing date except under enumerated circumstances). Despite their small statutory footprint, a robust doctrinal and theoretical edifice has been built on these disclosure and publication provisions. The disclosure theory of patent law portrays a patent as a "bargain" between an inventor and the public. Bonito Boats, Inc. v. Thunder Craft Boats, Inc., 489 U.S. 141, 15051 (1989); Pfaff v. Wells Elecs., Inc., 525 U.S. 55, 63 (1998). It depicts the patent regime as a simple quid pro quo: in return for granting the patentee a temporally limited right to exclude from the claimed embodiments, the public gets the benefit of access to and use of information about the invention that the patentee could have chosen to keep secret. J.E.M. Ag Supply, Inc., 534 U.S. at 142 (quoting Kewanee Oil Col. v. Bicron Corp., 416 U.S. 470, 484 (1974)). Importantly, this benefit includes unrestricted access to and use of the inventive information itself during the term of the patent. Members of the public can access and copy the information about an invention, profit from the information by presenting it as an expert for a fee and use the information as a springboard to improve on and/or design-around the claimed invention-all without the authorization of the patentee. This access and use in turn allows the patentee's competitors to improve on and/or design around the claimed invention before the expiration of the patent term. See 1 DoNALD S. CHISUM, CHISUM ON PATENTS $\$ 7.01$ (2007) ("On [publication] the patent immediately increases the storehouse of public information available for further research and innovation."). 
grants a limited privilege of access to a person in need for the duration of the need, regardless of consent of the owner.45

The unique dualism of the patent regime derives from the fact that the claims (i.e., the inventor's right to exclude) and the disclosure (i.e., the public's privileges of use and access) govern distinct resources. Claims describe and propertize "embodiments" of inventive information-things like vials of isolated Protein X or mousetraps that can catch mice. In contrast, disclosures convey and "publicize" 46 the inventive information qua information, i.e., the information that demonstrates inter alia the novelty, nonobviousness, and utility of the embodiments. Even as the claimed embodiments of the inventive information are placed under the control of the patentee, the information about the invention is "exacted" from the patentee 47 and made free for all to use in a public domain. Through the disclosure, information about Protein X's structure and information about how the mouse trap catches mice is released to the public for use without condition. 48

A structural theory of Section 101 assigns to the patentable subject matter doctrine the role of protector of one side of the duality, the public privilege to access and use inventive information, from encroachment by the other, the private right of the patentee to exclude others from the claimed invention. An inventor can easily come up with claim language that describes a resource that is nothing more than inventive information qua information. For example, as already discussed, she can claim "a representation of the structure of Protein $\mathrm{X}$ recorded on a tangible medium." Whenever a claim, such as this one, describes and therefore purports to propertize inventive information qua information, the claim should be held to recite unpatentable subject matter. Without a structural theory of Section 101, there is no patent law doctrine that ensures that the patentee makes the information that she must disclose freely available to the public, and patentees arguably could claim information qua

\footnotetext{
45 See generally RESTATEMENT (SECOND) OF TORTS §§ 191-211 (1977) (listing privileged entries to land irrespective of any transaction between the parties).

46 "Publicize" is used here in the sense of granting privileges of both access and use to the public, not merely in the sense of making the existence of the resource known to the public.

47 Eldred, 537 U.S. at 216.

${ }^{48}$ There is, of course, one condition on how the public can use the information: they cannot use it to make a patentable embodiment that falls within the scope of a valid claim.
} 
information. 49 If they were to succeed, only the residual information that happened to be left over after the figure of the claim had been delineated would be freely available, and the public domain of the disclosure side of the duality would flow from patentees' errors of under-claiming, not from any substantive obligation placed on the patentees.

Clearly, there is nothing in the literal text of Section 101 when examined in isolation that suggests that courts should be protecting the duality of the patent regime and preventing encroachment by claims into the realm of the disclosure. Entitled "Inventions Patentable," Section 101 merely states that "[w]hoever invents or discovers any new and useful process, machine, manufacture or composition of matter, or any new and useful improvement thereof, may obtain a patent therefore, subject to the conditions and requirements of this article title." ${ }_{50}$ Most attempts to look for an interpretation of the patentable subject matter doctrine that are grounded in the statutory text zoom in to a narrow frame, undertake an exegesis of the four terms "process, machine, manufacture or composition of matter," and query whether there is some type of subject matter that falls between the cracks of these four categories. ${ }^{11}$

A structural statutory argument, however, looks at the words of the statute not in isolation, but in the context of the statutory scheme as a whole.52 When Section 101 is viewed in the context of the disclosure provisions and the claiming/disclosing duality, it is clear that there is at least one thing that is not a patentable "process, machine, manufacture or composition of matter": the inventive information qua information that is "exacted" from the patentee by the disclosure requirements 53 and that must, as a consequence, be made freely available to all.

\footnotetext{
49 See supra notes 30-40 and accompanying text (arguing that claims to inventive information qua information are arguably novel, nonobvious and statutorily useful and that the best statutory locus for a rule prohibiting their patentability lies in Section 101).

${ }^{50} 35$ U.S.C. $\S 101$ (2007).

${ }^{51}$ See, e.g., In re Nuijten, 500 F.3d at 1351-58.

${ }^{2}$ See United Savs. Ass'n of Tex. v. Timbers of Inwood Forest Assocs., Ltd., 484 U.S. 365, 371 (1988) (Scalia, J.) ("Statutory construction . . . is a holistic endeavor."); 2A NORMAN J. SINGER, SUTHERLAND STATUTORY CONSTRUCTION $\$ 46.05$ (7th ed. 2007) (discussing the principle of "whole statute" interpretation).
}

53 Eldred, 537 U.S. at 216. 
From a policy perspective, an interpretation of Section 101 that encompasses the role of protecting the structural claiming/disclosing duality reflects the "basic tools" rationale that the Supreme Court has already articulated as a motivating concern of the subject matter patentability doctrine.54 Each side of the duality seeks to promote progress through a different mechanism. The right of patentees to exclude others from claimed embodiments overcomes the free-rider problem that makes an unstructured market for inventive information fail. It augments the incentive to generate inventive information where it is possible that insufficient incentives otherwise may exist.

In contrast, the disclosure requirement and its public-domain approach establish a system whereby the inventors of generation $\mathrm{N}$ reduce the costs of innovation of the inventors of generation $\mathrm{N}+1$. The disclosure makes sure that inventive information-a non-fungible resource that is commonly used as an input into the inventive process, i.e., a "basic tool"-is freely available to all future inventors. 55 It does so, however, only if a structural theory of Section 101 protects it from encroachment by the propertizing effect of the claims. In sum, a structural theory of Section 101 suggests that inventive information qua information should be a "spillover" of property in innovation and an example of why and how an inventor should not internalize the full social value of her invention. $5^{6}$

\section{EVERYTHING IS INFORMATION?}

One difficulty with developing a structural theory of Section 101 that treats information qua information as unpatentable subject matter is that the PTO routinely allows (and the courts routinely sanction) patent claims that describe states of being that we intuitively understand to be information-bearing states. Claims to isolated and

54 See supra notes 18-21 and accompanying text (outlining the "basic tools" justification of the prohibition on claims to "laws of nature" in the abstract).

$55 \mathrm{~A}$ bar on claims to inventive information qua information is also required to ensure that rights to exclude from information qua information do not create distortions in the marketplace of ideas that the First Amendment is designed to safeguard. See Abrams v. United States, 250 U.S. 616, 630 (1919) (Holmes, J., dissenting).

${ }^{56}$ Brett M. Frischmann \& Mark A. Lemley, Spillovers, 107 CoLUM. L. REv. 257, 257 (2007) (explaining the positive role of "spillovers" from patents that are defined by the fact that "the social value of innovations far exceeds the private value"). 
purified $\mathrm{DNA}^{57}$ and computer software recorded on tangible storage media ${ }^{5}$ are readily viewed as claims to information. The problem extends beyond the self-evidently borderline cases as it is possible to describe all claims in some technological fields as claims to information.59 If we do not want a structural theory of Section 101 to undermine the entire patent regime, we must be able to distinguish claims describing unpatentable states of being that convey inventive information qua information from claims describing patentable embodiments of that same inventive information. Currently, we have no such taxonomy of information.

One possible, but ultimately unsuccessful, solution to this problem is to use immateriality as a proxy for information qua information. ${ }^{60}$ In In re Nuijten, the Federal Circuit recently announced that a claim to an information-carrying "signal" is not patentable subject matter because it is too intangible to be a "manufacture" under Section 101.61 Following this materiality approach, however, a claim recites a propertizable embodiment rather than information qua information so long as it describes a tangible thing that has material existence in

57 See Rebecca S. Eisenberg, Molecules v. Information: Should Patents Protect Both?, 8 B.U. J. SCI. \& TECH. L. 190, 196 (2002) (panel presentation) ("You know, of course, the truth is that DNA sequences are both molecules and information. They are informational molecules, and it is not clear where to put these informational molecules in a taxonomy that distinguishes tangible embodiments from intangible information.").

${ }^{8} 8$ In re Beauregard, 53 F.3d 1583 (Fed. Cir. 1995) (acquiescing to claims to computer software drawn to describe software stored on a tangible medium). In re Beauregard seems to create an acute problem of subject matter patentability under a structural claims like those in theory of Section 101 because it is possible to infringe a Beauregard claim merely by sharing information about the invention, i.e. the software code. (I thank Mark Lemley for this observation.) $C f$. Eisenberg, supra note 5, at 794-95 (arguing that a claim to a DNA sequence in computer-readable form would violate the spirit of the traditional disclosure-for-exclusive-rights bargain of the patent regime). The difficulties that the informational nature of software creates for the patent regime extend beyond In re Beauregard claims. See Microsoft Corp. v. AT\&T Corp., 127 S.Ct. 1746 (2007) (holding that computer software can be a "component" under Section 271(f), but that it is not "supplie[d] ... from the United States" when the material instantiation of the code sent from the United States is copied onto a computer abroad).

59 Dan L. Burk, The Problem of Process in Biotechnology, 43 Hous. L. REv. 561, 582-88 (2006) (arguing that all claims to biotechnology inventions are claims to information).

${ }^{60} \mathrm{Cf}$. supra notes 26-29 and accompanying text (addressing recent cases raising intangibility as a limit on patentable subject matter).

${ }^{61}$ See, e.g., In re Nuijten, 500 F.3d at 1356-57. 
the world of extension. ${ }^{62}$ A materiality approach to Section 101 therefore proves to be insufficiently protective of the disclosing side of the claiming/disclosing duality because it allows claims and property to encroach into the public domain of the disclosure. The public domain of information qua information is useless if information only remains free for all to use when in a truly noetic state (if, in fact, information ever exists in a noetic state-a statement with which a materialist would clearly disagree). Only inscribed information is useful information.

Furthermore, in any system that uses information, there will always be points at which the information is inscribed in a sufficiently material form so as to be a "manufacture" under In re Nuijten. In fact, the very paradigm of a claim to information qua information introduced at the beginning of this article ("a representation of the structure of Protein X recorded on a tangible medium") is a claim to information qua information and yet it only describes material things or "manufacture[s]" under In re Nuijten. Under a structural theory of Section 101, the material substrate that is necessary to store and communicate inventive information qua information must be shielded from privatization in order to create a meaningful public domain. A bar on claims to intangible subject matter is not sufficient to ensure a bar on claims to inventive information qua information. ${ }^{3}$ Immateriality is neither the same quality as, nor a reasonable proxy for, the informationality that should be of concern in crafting the public domain of patent law. ${ }^{64}$ When Section 101 is viewed from a structural perspective, In re Nuijten is a red herring that may cause us to take our eyes off of the prize of a robust public domain of inventive information qua information.

62 Id. at 1351-52 (noting that the PTO allowed, and the Federal Circuit did not review a claim to "[a] storage medium having stored thereon a signal with embedded supplemental data"). It is important to note, however, that the claim at issue in In re Nuijten arguably is not an impermissible claim to information qua information despite its immateriality. Id. at 1368 (Linn, J., concurring in part and dissenting in part) ("Any information that [the claimed signal] conveys is wholly distinct from the invention itself; the [claim to the] signal is a [claim to an] information carrier, not an attempt to claim information itself.").

${ }_{63}$ In addition to being underinclusive with respect to the claims to information qua information that should be excluded from patentable subject matter under a structural theory of Section 101, a bar on intangible signals is also arguably overinclusive. See supra note 62 .

${ }^{64} \mathrm{Cf}$. In re Nuijten, $500 \mathrm{~F} .3 \mathrm{~d}$ at 1366 (Linn, J., concurring in part and dissenting in part) ("As a matter of principle, there is little reason to allow patent claims to otherwise unpatentable, deemed abstractions just because those deemed abstractions are stored in a tangible medium ...."). 


\section{CONCLUSION}

Thus, as promised, this article ends by bringing into focus the most difficult obstacle that a structural theory of Section 101 must surmount. The important question going forward is not whether there are blatant claims to inventive information qua information that courts applying Section 101 do and should label as unpatentable subject matter. Clearly, there are, and a structural theory of Section 101 provides a narratively coherent, policy driven and statutorily justified basis for courts to make these decisions. Rather, the important question is: how can we separate the patentable claims to tangible, information-bearing states of being from the unpatentable ones?

Information is a broad and, more importantly, polyvalent concept. If a structural theory of Section 101 is to be of practical use, then we need a taxonomy of the different ways in which tangible states of being can be informational or, perhaps, possess informationality. ${ }^{65}$ We must restrict the scope of the structural theory's claim-denying impact to the types of claims to information in which the relevant policy concerns are at their strongest. This suggestion, however, is obviously more of a point of departure than it is a sign of arrival. There is much, much more that must be said to develop such a taxonomy, argue that its categories are administrable, and demonstrate that it can distinguish those claims that, from a policy perspective, should be held to recite patentable information from those claims that should not. 66

\footnotetext{
${ }_{65}$ See Burk, supra note 59, at 584 (noting the need for "some rigor to the use of the term 'information' in the 'information patents' argument"). Cf. In re Nuijten, 500 F.3d at 136667 (Linn, J., concurring in part and dissenting in part) (noting the need to differentiate between "patentable inventions involving the manipulation or transmission of information from unpatentable inventions whose only utility lies in the particular information they convey" and the difficulty of drawing this line).
}

${ }^{66}$ See Kevin Emerson Collins, Patentable and Unpatentable Information (on file with author) (mining the philosophy of information for distinctions in the ways in which tangible states of being are informational and searching for policy-driven proxies to differentiate patentable and unpatentable claims to information). 
